\title{
Comparison of the immune response to Epstein-Barr virus and cytomegalovirus in sera and synovial fluids of patients with rheumatoid arthritis
}

\author{
M MUSIANI, ${ }^{1}$ M ZERBINI, ${ }^{1}$ S FERRI, ${ }^{2}$ M PLAZZI, ${ }^{1}$ G GENTILOMI, \\ AND M LA PLACA \\ From the ${ }^{1}$ Institute of Microbiology and the ${ }^{2}$ Department of Rheumatology, University of Bologna, Via \\ Massarenti 9, Bologna, Italy
}

SUMMARY The immune response against two herpesviruses has been determined in sera and matched synovial fluids of patients with rheumatoid arthritis (RA) and compared with that of a healthy control population. The increased level of antibody to Epstein-Barr virus (EBV) induced antigens in patients with RA resembles the antibody pattern observed against cytomegalovirus (CMV) induced antigens, which suggests the presence of a pathological condition in patients with RA that can reactivate latent viral infections. The antibody response against EBV and CMV observed in synovial fluids excludes the local production of specific antibodies against EBV and CMV antigens.

Several pieces of indirect evidence have suggested a possible role for viruses in the pathogenesis of rheumatoid arthritis (RA). Although it has been argued recently that parvovirus infection may be the initial cause of rheumatoid arthritis, ${ }^{1}$ the EpsteinBarr virus (EBV) has more frequently been postulated as a causative agent. As is known, EBV is an ubiquitous member of the Herpesviridae family, and its infection is often asymptomatic. In fact, by the time of young adulthood, most people have serum antibodies to EBV, which are markers of prior infection. In addition, together with the other herpesviruses, EBV shares the capacity of remaining latent in infected individuals until an appropriate stimulus or a lowering of immune barriers, or both, causes the reactivation of the latent infection.

Several experimental observations have supported the role of EBV in RA pathogenesis. It is known that (a) patients with RA have raised antibody titres against EBV induced antigens, ${ }^{23}$ including the nuclear antigen EBNA $\mathrm{I},{ }^{4}$ encoded by the IR-3 region of the EBV genome; (b) RA T cells have difficulty limiting the outgrowth of EBV infected B cells; $;^{5}$ and $(c)$ there is a greater prevalence of EBV transformed $B$ cells in the blood of

Accepted for publication 10 May 1987.

Correspondence to Dr M Musiani, Institute of Microbiology, Via Massarenti 9, 40138 Bologna. Italy. patients with RA. ${ }^{6}$ Furthermore, RA synovial membrane contains a 62 kilodalton protein that shares an antigenic epitope with the EBV encoded associated nuclear antigen. ${ }^{7}$

It is now clear, however, that if EBV has a role in the pathogenesis of RA, it cannot be considered as the sole aetiological agent. Indeed, several studies have reported RA patients without antibodies to EBV induced viral capsid antigens (VCA). ${ }^{89}$ Moreover, recent reports have shown a lack of reactivity of RA synovial membrane DNA with cloned EBV DNA probes. ${ }^{10}$ This suggests that the 62 kilodalton antigen in RA synovial lining is probably encoded by cellular genes which are similar to the IR-3 region of EBV genome and so it does not result from EBV infection of the RA synovial membrane.

Patients with RA generally show higher titres of antibodies to EBV induced VCA, EBNA, and early antigens (EA) than control populations. This serological condition is similar in some respects to the one seen in immunologically compromised individuals, ${ }^{11}$ where the disturbance of the virushost balance is an inevitable consequence of impairment of the cell mediated immune response. ${ }^{12}$

It is known that another member of the Herpesviridae family, cytomegalovirus, can be reactivated in an immunocompromised host ${ }^{13}$ and that antibody to cytomegalovirus induced early 
antigens (EA) is present in high levels in early rheumatoid disease. ${ }^{14}$ Thus the aim of our study was to determine the relevance of the immune response against EBV induced VCA, EA, and EBNA, and against CMV induced late antigens (LA), EA, and immediate early antigens (IEA) in order to determine a serological pattern against both viruses.

\section{Materials and methods}

SERA AND SYNOVIAL FLUIDS

Serum samples were collected from 35 patients with classical or definite RA, with an age range of 28-65 years.

The patients with RA met the American Rheumatism Association criteria for diagnosis. ${ }^{15}$ Twenty seven of them were rheumatoid factor positive at the time of the study. All 35 patients were taking non-steroidal anti-inflammatory agents. Twenty RA patients received $\leqslant 12 \mathrm{mg}$ of prednisone daily, three patients were receiving steroidal agents and gold, eight patients were receiving gold therapy, two patients were receiving antimalarial agents and steroidal agents, and two patients were receiving only non-steroidal anti-inflammatory agents. All the 35 patients with RA were in an active inflammatory phase of the disease. A specimen of synovial fluid was collected from 19 of the 35 patients. As control, serum samples were collected from 40 healthy volunteers matched for age and sex.

DETECTION OF ANTIBODY TO EBV

Antigen preparations

To prepare EBV induced VCA the cell suspension from one bottle of P3HR1 cells was centrifuged at $1000 \mathrm{rpm}$ for $10 \mathrm{~min}$, and the cell pellet was reconstituted in $0.5 \mathrm{ml}$ of phosphate buffered saline (PBS) $(0 \cdot 15 \mathrm{M}, \mathrm{pH} 7 \cdot 4)$. Drops of cell suspension were applied to a slide; the cell density of each spot was checked microscopically, and the concentration was adjusted, if necessary, to give an almost confluent cell smear. The slides were air dried, fixed in acetone at $4^{\circ} \mathrm{C}$ for $15 \mathrm{~min}$, and then stored at $-20^{\circ} \mathrm{C}$. A reference serum (MLZ 78 , VCA titre 1/320, EA titre negative, EBNA titre 1/80) was used to test antigen preparation and showed 5-8\% VCA positive cells. ${ }^{16}$ To prepare EBV induced EA Raji cells treated with $50 \mu \mathrm{g} / \mathrm{ml}$ of 5-iododeoxyuridine (Sigma Chemical Co) for $72 h^{17}$ were processed as described above. EA preparations were tested with a reference serum (EJ 77, EA titre 1/1280), showing between 5 and $15 \%$ EA positive cells. To detect antibodies to EBNA Raji cells were used as antigen source and were processed as described above. ${ }^{18}$

IMMUNOALKALINE PHOSPHATASE ASSAY An immunoalkaline phosphatase assay for the detection of antibody to EBV induced VCA and $E A$ 음 was performed as previously described. ${ }^{19}{ }^{20}$ In brief acetone fixed cells were treated with serial twofolds dilutions of sera and synovial fluids at $37^{\circ} \mathrm{C}$ for 450 min. After three washes in PBS, alkaline phospha등 tase labelled goat immunoglobulins to human im munoglobulin were added. Cells were then incus bated at $37^{\circ} \mathrm{C}$ for $45 \mathrm{~min}$; after a further threen washes in PBS the alkaline phosphatase substrate was added. The alkaline phosphatase label was? developed with a naphthol salt as a coupling agent $\vec{\omega}$ and a diazonium salt (fast blue) as a capture agent $\stackrel{\omega}{\mathcal{D}}$ forming an insoluble dark blue precipitate at the site of enzyme localisation.

IMMUNOFLUORESCENCE ASSAY

Antibodies to EBNA were titrated by an anticom plement immunofluorescence assay on Raji cells fixed in acetone:methanol (2:1). As reference serum, MLZ 78 (VCA titre 1/320, EA titre negative $\overrightarrow{+}$ EBNA titre 1/80) was used. ${ }^{18}$ An EBV active oz recent primary infection was indicated by the concomitant presence of anti-VCA titres $\geqslant 1 / 32 \notin$ and anti-EA titres $\geqslant 1 / 20$ in the absence of antibod to EBNA. An EBV active or recently reactivated infection was defined by the concomitant preseme of anti-VCA titres $\geqslant 1 / 320$, anti-EA titres $\geqslant 1 /$ 总.; and EBNA titres $\geqslant 1 / 10$. $^{21}$

DETECTION OF ANTIBODY TO CMV

Antigen preparations

To prepare CMV induced IEA, human embry용 fibroblasts infected with the Towne strain of CM and grown on coverslips were fixed in acetone on호 hour after infection.

CMV induced EA were prepared by fixing cells infected in the presence of $75 \mu \mathrm{g} / \mathrm{ml}$ of cytarabine $72 \mathrm{~h}$ after infection, to accumulate all EA synthesise before replication of viral DNA.

CMV induced $\mathrm{LA}$ were obtained by fixing $\mathrm{CM}$. infected cells $72 \mathrm{~h}$ after infection. To test antige $\widehat{P}$ preparations a reference serum was used (BE $184 ?$ anti-LA titre $1 / 640$, anti-EA titre $1 / 320$, anti-IEA titre $1 / 160)$.

\section{Alkaline phosphatase assay}

An alkaline phosphatase assay to detect antibodies to CMV was performed in human sera and synovian fluids as described above. Active or recent CMW infection was diagnosed serologically by the con $\omega$ comitant presence of a titre of anti-CMV induced $\mathrm{LA} \geqslant 1 / 320$, a titre of anti-CMV induced $\mathrm{EA} \geqslant 1 / 20$ and a titre of anti-IEA $\geqslant 1 / 20 .^{22}$

ST A T IS T I CS

The statistical significance of results was determine with Student's two tailed $t$ test. 


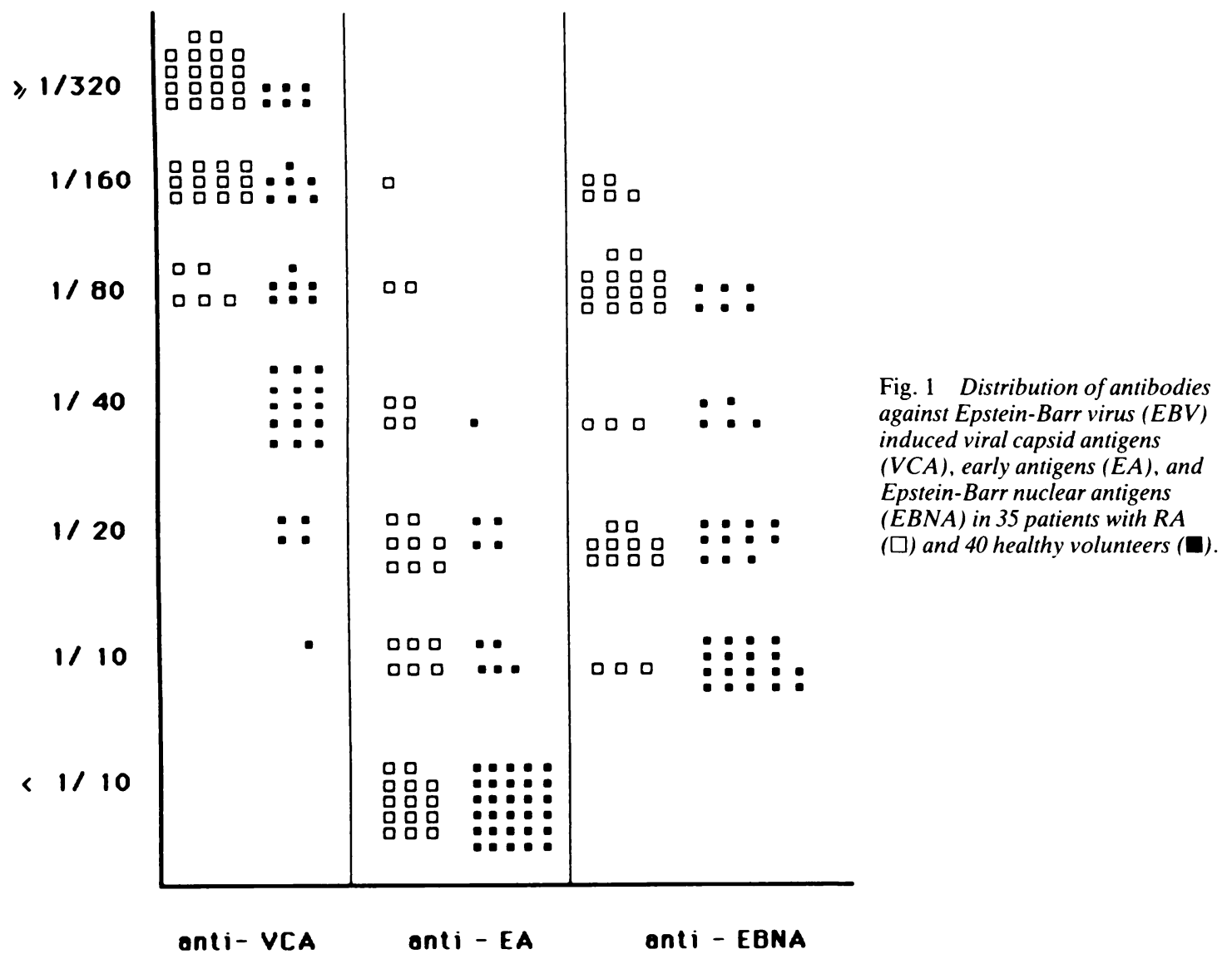

\section{Results}

The distribution of antibody values against EBV induced VCA, EA, and EBNA in the 35 patients with RA and in the control population is shown in Fig. 1. In the sera of the 35 patients with RA the antibody values against EBV induced VCA, EA, and EBNA were significantly higher $(p<0 \cdot 01)$ than those for healthy controls.

Of the 35 patients with RA, 18 patients $(51.4 \%)$ had anti-VCA antibodies with titres $\geqslant 1 / 320$, while only six $(15 \%)$ of 40 healthy controls had values $\geqslant 1 / 320$. The geometric mean titre of anti-VCA antibodies was $1 / 290$ in the patients with RA and only $1 / 68$ in healthy controls. Antibodies against EBV induced EA were present with titres $\geqslant 1 / 20$ in $15(42.8 \%)$ of the 35 patients with RA, in comparison with five $(12.5 \%)$ of 40 healthy control volunteers.

All the antibody titres against EBNA for the patients with RA and for the healthy controls were positive. Of the 35 patients with RA, 19 (54.2\%) had anti-EBNA antibody titres $\geqslant 1 / 80$ compared with only six of the 40 controls $(15 \%)$. Moreover, the geometric mean titre of antibodies against EBNA in patients with RA was $1 / 46$, while in healthy controls it was $1 / 27$.

All patients with RA and all control subjects had detectable antibody to VCA and EBNA, indicating that all had previously been infected with EBV. As a consequence no primary EBV infections were noted, either in patients with RA or in healthy control volunteers. On the other hand, among the patients with RA, $14(40 \%)$ of the 35 had serological signs of reactivated EBV infection (VCA $\geqslant 1 / 320$, $\mathrm{EA} \geqslant 1 / 20$, and EBNA $\geqslant 1 / 10$ ), while in the control population only five $(12.5 \%)$ of the 40 observed had serological signs of reactivated infections.

The distribution of antibody values against CMV induced LA, EA, and IEA in the 35 patients with RA and in the control population is shown in Fig. 2. Seventeen patients with RA $(48.5 \%)$ out of the 35 observed had antibody titres against CMV induced LA $\geqslant 1 / 320$, while only five control volunteers 


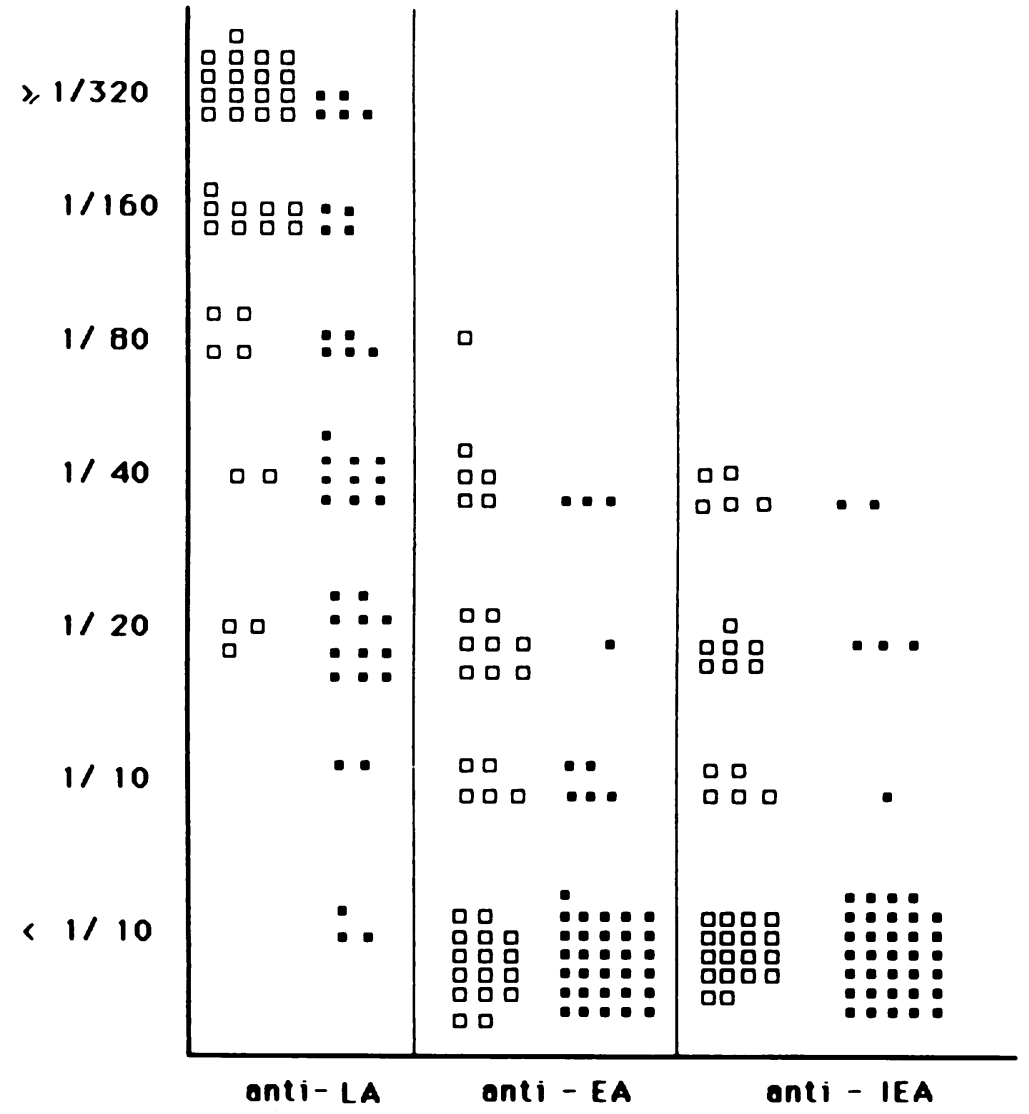

Fig. 2 Distribution of antibodies के against cytomegalovirus (CMV) induced late antigens $(L A)$, early $\overrightarrow{\dot{\infty}}$ antigens $(E A)$, and immediate $\omega^{\infty}$ early antigens (IEA) in 35 patients with $R A(\square)$ and 40 healthy volunteers (ם).

$(12 \cdot 5 \%)$ out of 40 observed had values $\geqslant 1 / 320$. The geometric mean titre against LA in patients with RA was $1 / 185$, while in the control population it was $1 / 39$.

Fourteen patients with RA $(40 \%)$ had titres against $\mathrm{CMV}$ induced $\mathrm{EA} \geqslant 1 / 20$, while only four control volunteers $(10 \%)$ had anti-EA titres $\geqslant 1 / 20$. Antibody values against CMV induced IEA were $\geqslant 1 / 20$ in $12 / 35$ patients with RA $(34 \cdot 2 \%)$ and in $5 / 40$ healthy controls $(12 \cdot 5 \%)$. The antibody titres against CMV induced antigens were significantly higher in patients with $R A$ than in controls $(p<0.01$ for antibody to LA and EA, and $p<0.05$ for antibody to IEA). Serological signs of CMV active or recent infection (antibodies anti-LA $\geqslant 1 / 320$, antibody to EA $\geqslant 1 / 20$, and antibody to IEA $\geqslant 1 / 20$ ) were present in $12(34.2 \%)$ of the 35 patients with RA and in three $\mathbf{( 7 . 5 \% )}$ of the $\mathbf{4 0}$ healthy controls.

The serum and synovial fluid antibody titres to EBV induced VCA and CMV induced LA in paired samples from 19 patients with RA are shown in Table 1. In all synovial fluids the antibody titres against EBV induced VCA and CMV induced LA,
Table 1 Serum synovial fluid antibody titres to $E B V$ induced VCA and CMV induced LA in paired samples from 19 patients with rheumatoid arthritis

\begin{tabular}{|c|c|c|}
\hline \multirow[t]{2}{*}{ Patient No } & \multicolumn{2}{|c|}{ Serum/synovial fluid antibody titres to: } \\
\hline & $E B V$ induced $V C A$ & $C M V$ induced \\
\hline 1 & $320 / 80$ & $640 / 80$ \\
\hline 2 & $160 / 40$ & $640 / 640$ \\
\hline 3 & $80 / 20$ & 20/neg. \\
\hline 4 & $320 / 160$ & $640 / 160$ \\
\hline 5 & $160 / 80$ & $160 / 40$ \\
\hline 6 & $640 / 160$ & $160 / 40$ \\
\hline 7 & $640 / 160$ & $160 / 40$ \\
\hline 8 & $80 / 20$ & $640 / 160$ \\
\hline 9 & $160 / 80$ & $320 / 80$ \\
\hline 10 & $1280 / 160$ & $320 / 40$ \\
\hline 11 & $2560 / 320$ & $160 / 80$ \\
\hline 12 & $320 / 40$ & $320 / 160$ \\
\hline 13 & $160 / 40$ & $320 / 80$ \\
\hline 14 & $160 / 40$ & $80 / 20$ \\
\hline 15 & $640 / 160$ & $320 / 80$ \\
\hline 16 & $320 / 80$ & $80 / 40$ \\
\hline 17 & $160 / 40$ & $320 / 40$ \\
\hline 18 & $640 / 80$ & $640 / 160$ \\
\hline 19 & $80 / 20$ & $320 / 80$ \\
\hline
\end{tabular}


although at high titres, were lower or equal (in one sample) than those obtained from the matched sera.

\section{Discussion}

The results of the present study show that in the sera of patients with RA there is a statistically significant increase of antibody titres to EBV induced VCA, EA, and EBNA, in comparison with healthy control volunteers. In the same RA patients, however, an increased incidence of antibodies was also noted against CMV induced LA, EA, and IEA. Both EBV and CMV serological patterns showed signs of active or recent infections.

Similar enhancements of anti-EBV and anti-CMV antibodies, compared with controls, is also shown in some other connective tissue diseases and in a variety of non-malignant or malignant illnesses, ${ }^{23-26}$ all having immunosuppressive effects or requiring immunosuppressive therapy. The impaired immune response in these conditions is thought to activate the latent persistent viral carrier state that regularly ensues after primary EBV or CMV infections. Comparative titrations of paired sera and synovial fluids from 19 patients with RA yielded antibody titres reflecting the normal ratio of gammaglobulins found in sera and synovial fluid. ${ }^{27}$ The antibody titres, either against EBV induced VCA or against CMV induced LA, were at lower level in synovial fluid, i.e., about one quarter, than in matched serum samples. This observation indicates that the presence of antibodies to EBV and CMV in synovial fluids merely reflects their presence in the sera, rather than suggesting a local production of specific immunoglobulins. The results obtained here suggest that quantitative changes in the EBV and CMV carrier state of patients with RA seem to be a consequence, rather than a cause, of the persistent inflammatory response which characterises rheumatoid arthritis. This does not, however, exclude the possibility that persistent EBV or CMV infection is important in the perpetuation of the rheumatoid process.

The work was partially supported by Consiglio Nazionale delle Ricerche Progetto Finalizzato 'Controllo delle Malattic da Infezionc' grants Nos 86.01595.52 and 86.01643.52.

\section{References}

1 Simpson R W. McGinty L. Simon L, Smith C A. Godzeski C W, Boyd R J. Association of parvovirus with rheumatoid arthritis of humans. Science 1984; 223: 1425-8.

2 Catalano M A. Carson D A, Niederman J C. Feorino P. Vaughan J H. Antibody to rheumatoid arthritis nuclear antigens: its relationship to in vivo Epstein-Barr virus infection. $J$ Clin Invest 1980; 65: 1238-42.

3 Alspaugh M A, Henle G, Lennette E T, Henle W. Elevated levels of antibodies to Epstein-Barr virus antigens in sera and synovial fluids of patients with rheumatoid arthritis. $J$ Clin Invest 1981; 67: 1134-40.

4 Rhodes G, Carson D A, Valbracht J, Houghten R, Vaughan $J$ H. Human immune responses to synthetic peptides from the Epstein-Barr nuclear antigen. $J$ Immunol 1985; 134: 211-6.

5 Depper J M, Bluestein H G, Zvaifler N J. Impaired regulation of Epstein-Barr virus induced lymphocyte proliferation in rheumatoid arthritis is due to a T cell defect. $J$ Immunol 1981; 127: 1899-902.

6 Tosato G, Steinberg A D, Yarchoan R, et al. Abnormally elevated frequency of Epstein-Barr virus infected $B$ cells in the blood of patients with rheumatoid arthritis. J Clin Invest 1984; 73: $1789-95$.

7 Fox R I, Sportsman R. Rhodes G H, Luka J, Pearson G, Vaughan $\mathbf{J} \mathbf{H}$. Rheumatoid arthritis synovial membrane contains a $62 \mathrm{Kd}$ protein that shares an antigenic epitope with the Epstein-Barr virus-encoded EBNA-1 antigen. J Clin Invest 1986; 77: $1539-47$.

8 Ferrel P B, Aitcheson C T, Pearson G R, Tan E M. Seroepidemiological study of the relationship between EpsteinBarr virus and rheumatoid arthritis. J Clin Invest 1981; 67: 681-7.

9 Depper J M, Zvaifler N J. Epstein-Barr virus: its relationship to the pathogenesis of rheumatoid arthritis. Arthritis Rheum 1976; 19: 711-9.

10 Fox R I, Chilton T. Rhodes G. Vaughan J H. Lack of reactivity of rheumatoid arthritis synovial membrane DNA with cloned Epstein-Barr virus DNA probes. J Immunol 1986; 137: 498-501.

11 Henle W. Henle G. Epstein-Barr virus specific serology in immunologically compromised individuals. Cancer Res 1981; 41: 4222-6.

12 Crawford D H, Edwards J M B. Sweny P. Hoffbrand A V, Janossy G. Study on long-term $T$ cell mediated immunity to Epstein-Barr virus in immunosuppressed renal allograft recipients. Int J Cancer 1981; 28: 705-9.

13 The T H, Andersen H K. Spencer E S. Klein G. Antibodies against cytomegalovirus induced early antigens (CMV-EA) in immunosuppressed renal allograft recipients. Clin Exp Immunol 1977; 28: 502-5.

14 Male D, Young A, Pilkington C. Sutherland S, Roitt I M. Antibodies to EB virus- and cytomegalovirus-induced antigens in early rheumatoid disease. Clin Exp Immunol 1982; 50: 341-6.

15 Ropes M W. Diagnostic criteria for rheumatoid arthritis: 1958 revision. Ann Rheum Dis 1959; 18: 49-53.

16 Hinuma Y, Konh M, Yamaguchi J, Wuderski D J, Brakeslee J J, Grace J T. Immunofluorescence and herpes-type particles in the P3HR1 Burkitt lymphoma cell line. J Virol 1967; 1: 1045-51.

17 Veltri R, Wainwright W, Sprinkle P. Immunologic identification of Epstein-Barr virus early antigen in a P3HR1 extract. J Natl Canc Inst 1976; 57: 245-53.

18 Reedman B M. Klein G. Cellular localization of an EpsteinBarr virus (EBV) associated complement-fixing antigen in producer and non-producer lymphoblastoid cell lines. Int $J$ Cancer 1973; 11: 499-520.

19 Musiani M. Zerbini M. Gentilomi G, La Placa M. Indirect alkaline phosphatase immunoenzymatic staining for the detection of antibodies to Epstein-Barr virus induced virus capsid antigens and early antigens. J Clin Microbiol 1986; 23: 302-4.

20 Musiani M. Zerbini M. La Placa M. Rapid diagnosis of viral infections by an alkaline phosphatase immunocytochemical method. J Immunol Methods 1986; 88: 255-8.

21 Costa S. Terzano P. Zerbini M. Carpi C. Musiani M. Detection of active Epstein-Barr infection in pregnant women. Eur J Clin Microbiol 1985; 4: 335-6.

22 Zerbini M. Musiani M. Gentilomi G. La Placa M. Detection of 
842 Musiani, Zerbini, Ferri, Plazzi, Gentilomi, La Placa

specific immunoglobulin $M$ antibodies to cytomegalovirus by using monoclonal antibody to immunoglobulin $\mathbf{M}$ in an indirect immunofluorescence assay. J Clin Microbiol 1986; 24: 166-8.

23 Sumaya C V, Myers L W. Ellison G W. Epstcin-Barr virus antibodies in multiple sclerosis. Arch Neurol 1980; 37: 94-8.

24 Shillitoe E J. Danicls T E, Whitcher J P. Strand C V. Talal N. Grenspan J S. Antibody to cytomegalovirus in patients with Sjögren's syndrome as determined by an enzyme linked immunosorbent assay. Arthritis Rheum 1982: 25: 260-5
25 Sakamoto K. Aiba M. Katayama I, Sullivan J L. Humphreys R E. Purtilo D T. Antibodies to Epstein-Barr specific antigens in:patients with hairy cell lcukemia. Int J Cancer 1981: 27: 453-8. $\overrightarrow{\bar{F}}$

26 Giraldo G. Beth E. Huang E S. Kaposi's sarcoma and its relationship to cytomegalovirus (CMV). CMV DNA and CMVO early antigens in Kaposi 's sarcoma. Int $J$ Cancer 1980; 26: 23-9. 27 Decker B. McKenzie B. McGukin W F. Slocumb C H. Comparative distribution of proteins and glycoproteins of serum and synovial fluid. Arthritis Rheum 1959; 2: 162-7. 